\title{
PENAPISAN DAN IDENTIFIKASI BAKTERI PENGHASIL AGARASE DARI SAMPEL SEDIMEN LAUT BARA CADDI, SULAWESI SELATAN
}

\section{Screening and Identification of Agarase-producing Bacteria from Sediment Sample of Bara Caddi Sea, South Sulawesi}

\author{
Dewi Seswita Zilda ${ }^{1 *}$, Gintung Patantis', Sidiq Sakti Prawira², Mada Triandala Sibero², \\ dan Yusro Nuri Fawzya ${ }^{1}$ \\ ${ }^{1}$ Balai Besar Riset Pengolahan Produk dan Bioteknologi Kelautan dan Perikanan, \\ JI. KS Tubun, Petamburan VI, Jakarta Pusat, DKI Jakarta, 10260 Indonesia \\ 2 Tekno Park IImu Kelautan, Kampus Teluk Awur, Jalan UNDIP, Jawa Tengah, 59427, Indonesia \\ *Korespondensi Penulis: dewi.zilda@kkp.go.id
}

Diterima: 2 Oktober 2020; Direvisi: 25 Januari 2021; Disetujui: 11 Mei 2021

\begin{abstract}
ABSTRAK
Agarase adalah enzim yang mampu menghidrolisis agar menjadi oligoagar yang sudah banyak diaplikasikan dalam industri kesehatan dan kosmetika. Bakteri laut merupakan mikroba yang paling banyak dilaporkan sebagai sumber untuk isolasi bakteri penghasil agarase. Penelitian ini bertujuan untuk melakukan penapisan, isolasi, dan identifikasi bakteri penghasil agarase dari sedimen laut. Sampel sedimen diambil dari pantai Pulau Bara Caddi, Sulawesi Selatan. Penapisan dilakukan menggunakan media air laut yang ditambahkan tripton 0,5\%, ekstrak ragi $0,1 \%$, dan agar $2 \%$. Identifikasi dilakukan dengan amplifikasi gen $16 \mathrm{~S}$ rRNA. Sebanyak 45 isolat berhasil dimurnikan, 16 diantaranya merupakan bakteri penghasil agarase. Pola zona bening yang terbentuk terlihat berbeda-beda, hal ini diduga disebabkan oleh perbedaan jenis agarase yang dihasilkan oleh masing-masing isolat. Hasil penelitian menunjukkan bahwa terdapat 4 genera bakteri yang memiliki kemiripan yang tinggi dengan 16 isolat bakteri penghasil agarase yang terdapat pada sampel sedimen, yaitu Vibrio, Alteromonas, Salinivibrio, dan Marinobacter. Vibrio merupakan genus yang paling dominan diikuti oleh Alteromonas dan hanya satu isolat yang menunjukkan kesamaan dengan Salinivibrio dan Marinobacter.
\end{abstract}

KATA KUNCI : agarase, bakteri, Alteromonas, Vibrio, Marineobacter, Salinivibrio

\section{ABSTRACT}

Agarase is an enzyme that hydrolyze agar into agaro oligosaccharide which have been applied in health and cosmetic industries. Marine bacteria are the most widely reported microbes as a source for isolation of agarase-producing bacteria. This work was aimed to screen, isolate, and identify the agarase-producing bacteria from marine sediment. The sediment samples were collected from the sea around Bara Caddi Island, South Sulawesi. The screening of agaraseproducing bacteria was carried out using seawater media containing $0.5 \%$ tryptone, $0.1 \%$ yeast extract, and $2 \%$ agar. The identification of the bacteria obtained was carried out by amplification of the 16S rRNA gene. A total of 45 isolates were successfully purified, 16 of which were agaraseproducing bacteria. The clear zone formed on solid medium by some isolates showed different pattern which may be caused by the type of agarase produced by each isolate. The results showed that there were 4 genera of bacteria which similar to the 16 isolates agarase-producing bacteria found in sediment samples i.e. Vibrio, Alteromonas, Salinivibrio, and Marinobacter. Vibrio is the most dominant genus followed by Alteromonas and only one isolate showed similarity to Salinivibrio and Marinobacter.

KEYWORDS: agarase, bacteria, Alteromonas, $\underline{\text { Vibrio, }}$ Marineobacter, Salinivibrio

\section{PENDAHULUAN}

Agar merupakan polisakarida dari dinding sel rumput laut yang paling banyak terdapat pada rumput laut merah. Agar terdiri atas agaropektin dan agarosa yang memiliki struktur serupa (Jensen, 1993). Agarosa tersusun dari $\beta$ - (1-4) -D-galaktosa dan $\alpha$ - (1-3) -3,6anhidro-L-galaktosa (L-AHG) membentuk polimer rantai linier sedangkan agaropektin mengandung $\alpha$ 1, 3 - atau $\beta$-1-4- D-galaktosa dan 3,6-anhidro-Lgalaktosa ( $\mathrm{L}-\mathrm{AHG}$ ) yang difungsikan dengan gugus sulfat, piruvat, atau metil (Tanna \& Mishra, 2019). 
Secara luas, agar sudah digunakan dalam industri makanan sebagai bahan untuk memodifikasi tekstur dan bahan pengeras. Selain itu, di bidang mikrobiologi agar digunakan sebagai media tumbuh untuk isolasi dan pemurnian mikroorganisme.

Agar dapat didegradasi secara enzimatis dengan agarase, enzim hidrolitik yang diklasifikasikan berdasarkan sisi pemotongannya pada rantai agarosa. Agarase yang memecah ikatan $\alpha-1,3$ dalam agarosa disebut $\alpha$-agarase dan agarase yang memecah ikatan $\beta-1,4$ dikenal sebagai $\beta$-agarase. Berdasarkan database (http://www.cazy.org), $\alpha$-agarase secara fungsional diklasifikasikan ke dalam famili GH 96 dan $\beta$-agarase termasuk dalam empat famili, yaitu $\mathrm{GH} 16$, GH50, GH 86, dan GH118. $\alpha$ dan $\beta$ agarase menghasilkan agarooligosaccharides dan neoagarooligosaccharides (NAOS), masing-masing sebagai nonreducing sugars yang memiliki aplikasi di beberapa industri seperti obat-obatan, kosmetik, dan makanan. NAOS dilaporkan memiliki aktivitas biologis yang berperan sebagai antioksidan (Farahat, 2019) atau antimikroba (Kang et al., 2017). Campuran NAOS yang dihasilkan dari pemecahan agarase oleh agarase menunjukkan aktivitas penghambatan melanin dan $\alpha$-glukosidase yang dapat dikembangkan untuk bahan pemutih kulit (Kim, Yun, Yu, Kim, \& Kang, 2017), antidiabetes, dan antiobesitas (Hong et al., 2017). Agarase juga digunakan untuk pemurnian DNA dari gel agarosa (Zhang \& Sun, 2007) dan ekstraksi protoplas dari rumput laut merah (Dipakkore, Reddy, \& Jha, 2005).

Laporan tentang bakteri penghasil enzim $\alpha$-agarase masih sangat terbatas dan sampai saat paper ini ditulis baru dua bakteri yang dilaporkan menghasilkan $\alpha$-agarase, yaitu Alteromonas agalyticus GJ1B (Hassairi, Ben Amar, Nonus, \& Gupta, 2001; Potin, Richard, Rochas, \& Kloareg, 1993) dan Thalassomonas sp. JAMB-A33 (Ohta et al., 2005). Beberapa bakteri yang dilaporkan memproduksi agarase adalah Aquimarina agarylitica ZC1 (Lin, Liu, Lu, Zhao, \& Hu, 2017), Gayadomonas joobiniege G7 (Jung, Lee, Chi, Bae, \& Hong, 2017), Pseudoalteromonas sp. H9 (Chi et al., 2015), Stenotrophomonas (Zhu et al., 2016), Flammeovirga pasifica WPAGA1 (Hou, Chen, Chan, \& Zeng, 2015), Cellulophga omnivescoria W5C (Ramos, Valdehuesa, Nisola, Lee, \& Chung, 2018), Microbulbifer sp. AG1 (Zhu et al., 2019), dan Agarivorans gilvus WH0801 (Liang et al., 2017).

Lingkungan laut merupakan ekosistem dengan keanekaragaman hayati dan kimia yang tinggi, sehingga menjadi sumber yang menjanjikan untuk penemuan enzim baru. Banyak upaya yang dilakukan dalam menggali potensi lingkungan laut sebagai sumber enzim untuk industri. Meskipun beberapa enzim yang diisolasi dari organisme laut seperti ikan
(Haghparast, Moghanlou, Mohseni, \& Imani, 2019), udang (Javahery, Noori, \& Hoseinifar, 2019; Su et al., 2014), kepiting (She et al., 2019), dan alga (Mukai et al., 2019) telah dipelajari, tetapi enzim yang diproduksi oleh bakteri lebih diminati untuk dieksplorasi (Raveendran et al., 2018). Hal ini disebabkan produksi enzim dari bakteri lebih mudah untuk diekstraksi, dikultivasi, dan diaplikasikan di industri karena proses produksi yang efektif dan efisien (Cheng, Ismail, Kamaruding, Saidin, \& Danish-Daniel, 2020). Enzim yang dihasilkan oleh bakteri laut mungkin memiliki molekul protein unik dengan sifat baru seperti toleransi garam yang tinggi, hipertermostabilitas, barofilisitas, dan mampu beradaptasi pada lingkungan dingin (Giddings \& Newman, 2015; Rao, Imchen, \& Kumavath, 2017), sehingga menarik minat para ilmuwan untuk mempelajari. Mikroorganisme laut biasanya berasosiasi dengan organisme laut seperti spons laut, karang, dan spesies lainnya (Asagabaldan, Bedoux, \& Bourgougnon, 2019; Ayuningrum et al., 2017; Ayuningrum, Kristiana, Nisa, \& Radjasa, 2019; Kristiana et al., 2019a; Kristiana et al., 2019b).

Sedimen di perairan sekitar pantai maupun dari laut dalam serta air laut yang dapat dijangkau dan mudah dikumpulkan dapat menjadi sumber isolasi bakteri yang potensial. Sebagian besar bakteri laut penghasil agarase yang pernah dilaporkan diisolasi dari air laut atau merupakan simbion rumput laut. Tujuan penelitian ini adalah untuk menapis bakteri penghasil agarase dari sampel sedimen laut dan melakukan identifikasi terhadap bakteri yang sudah dimurnikan.

\section{BAHAN DAN METODE}

\section{Bahan}

Sedimen diambil dari laut di sekitar Pulau Bara Caddi, Sulawesi Selatan (5॰04'50.9"S 119¹9'09.6"E) (Gambar 1). Pengambilan sampel dilakukan dengan penyelaman pada kedalaman 8-10 meter. Sampel sedimen sebanyak $\pm 20 \mathrm{~g}$ dimasukkan ke botol konikal steril dan ditutup sebelum dibawa ke permukaan. Hal ini dilakukan untuk menghindari kontaminasi sampel oleh bakteri di kapal dan peralatan lain. Sampel kemudian disimpan dalam cool box yang telah diisi es untuk mempertahankan suhu dingin $\left( \pm 4^{\circ} \mathrm{C}\right)$. Setelah sampai di laboratorium, sampel disimpan dalam refrigerator $\left( \pm 4^{\circ} \mathrm{C}\right)$ sebelum digunakan untuk penelitian selanjutnya.

\section{Metode}

\section{Penapisan bakteri penghasil agarase}

Penapisan bakteri penghasil agarase dilakukan menurut Hu, Lin, Xu, Zhong, dan Liu (2009) dengan 


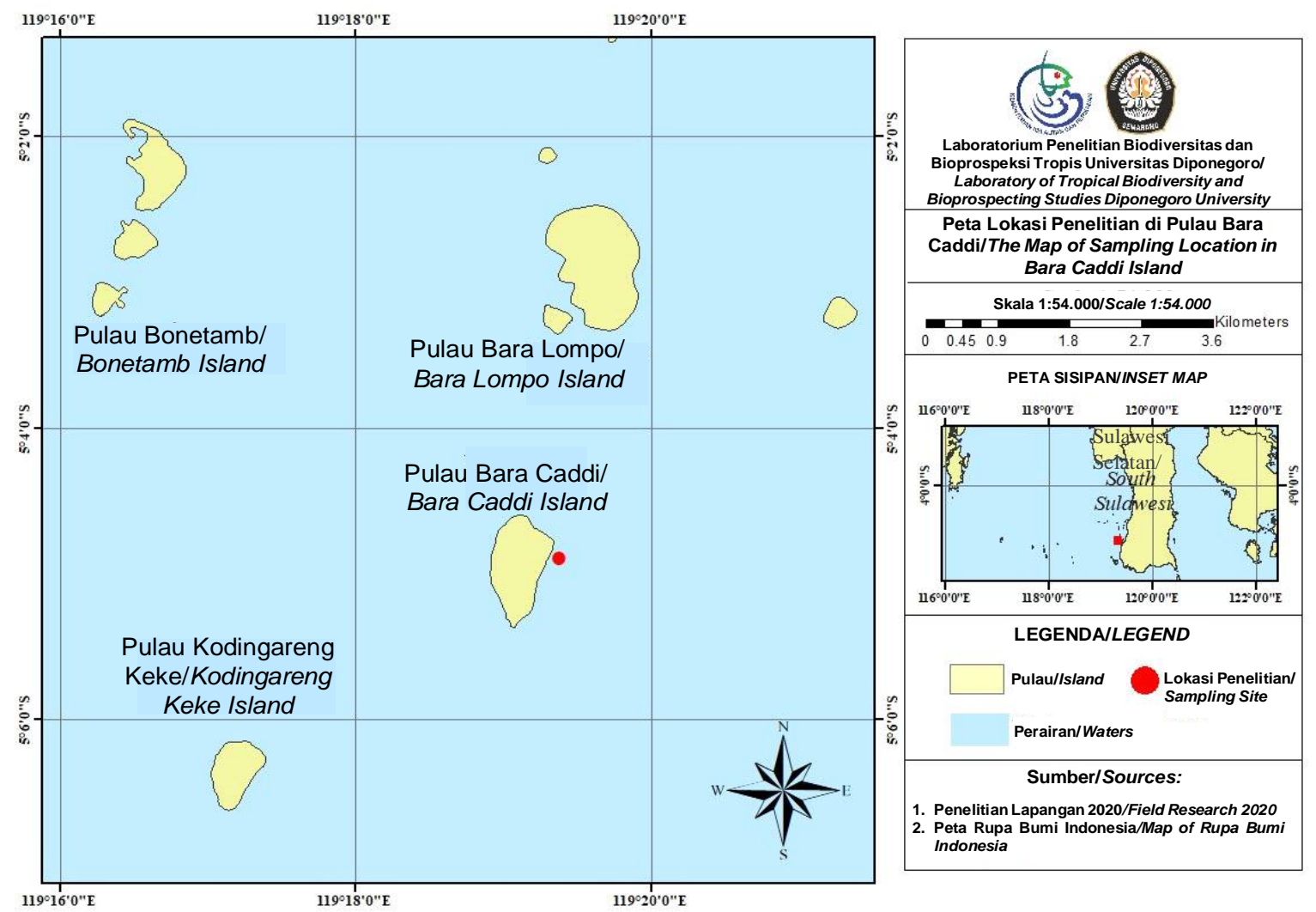

Gambar 1. Lokasi pengambilan sampel sedimen di perairan Pulau Bara Caddi yang merupakan bagian dari Kepulauan Spermoonde, Sulawesi Selatan, Indonesia.

Figure 1. The site of sediment samples collection, in the water of Bara Caddi Island which is part of Spermoonde Islands, South Sulawesi, Indonesia

modifikasi. Media air laut (MAL) untuk penapisan bakteri penghasil agarase dibuat dengan komposisi tripton $0,5 \%$, ekstrak yeast $0,1 \%$, dan agar $2 \%$ yang dilarutkan dengan air laut (30 ppt). Sebanyak $5 \mathrm{gr}$ sampel sedimen dimasukkan ke dalam botol yang telah berisi air laut steril dan divortex selama kurang lebih 10 menit untuk melepaskan bakteri yang menempel pada sedimen. Sampel air dari campuran sedimen diinokulasi ke media padat dengan serangkaian pengenceran $\left(10^{-5}-10^{-8}\right)$ kemudian diinkubasi selama 3-7 hari pada suhu $30^{\circ} \mathrm{C}$. Setiap koloni yang tumbuh pada media padat kemudian diisolasi dan dimurnikan.

Kemampuan bakteri dalam mendegradasi agarase dinilai dengan menginokulasi masing-masing isolat murni ke dalam MAL padat dan diinkubasi selama 24-48 jam. Larutan lugol (10\%) dituangkan pada plate agar dan diinkubasi selama 24 jam. Diameter koloni bakteri dan zona bening yang terbentuk diukur dan ditentukan nilai aktivitas kualitatifnya, yaitu indeks karbolotik (IK). Nilai IK diperoleh dari perbandingan antara diameter zona bening dan koloni bakteri. Transparansi zona bening dibagi dalam skala 1-5 dengan skala tertinggi untuk zona bening yang menunjukkan transparansi tertinggi. Penilaian dilakukan dengan meletakkan plate agar di bawah cahaya lampu dan didokumentasikan. Semua plate kemudian dikelompokkan berdasarkan tingkat transparansi zona bening yang terbentuk.

\section{Ekstraksi DNA}

Bakteri murni yang telah disegarkan pada MAL padat kemudian diinokulasikan ke dalam $50 \mathrm{~mL}$ MAL cair dan diinkubasi pada suhu $30^{\circ} \mathrm{C}$ di inkubator goyang pada 150 rpm selama 24 jam. Kultur bakteri kemudian disentrifugasi pada $10.000 \mathrm{~g}$ selama 10 menit. Sel pelet kemudian digunakan untuk ekstraksi DNA menggunakan Genomic DNA Purification Kit (Fermentas, Lithuania) berdasarkan protokol yang terdapat pada kit.

\section{Amplifikasi dan analisa gen 16S rRNA}

Reaksi PCR terdiri atas $1 \mu \mathrm{L}$ primer Forward (27F5'- AGAGTTTGATCCTGGCTCAG-3 '), primer Reverse $1 \mu \mathrm{L}$ (1492R-5-CGGTTACCTTGTTACGACTT-3 ‘) 
(Aravena et al., 2020), $25 \mu \mathrm{L}$ PCRmix (TIANGEN), $21 \mu \mathrm{L}$ air ultrapure dan $2 \mu \mathrm{LDNA}$. Ampilifikasi dilakukan menggunakan GeneAmp ${ }^{\circledR}$ PCR System 2700 kit (Applied Biosystems, Carla, CA, USA) dengan kondisi pra denaturasi pada suhu $94^{\circ} \mathrm{C}$ selama 5 menit yang dilanjutkan dengan 35 siklus denaturasi pada suhu $94^{\circ} \mathrm{C}$ selama 30 detik, anealing pada suhu $54^{\circ} \mathrm{C}$ selama 30 detik, dan ekstensi $72^{\circ} \mathrm{C}$ selama 90 detik. Reaksi diakhiri dengan post extension pada $72^{\circ} \mathrm{C}$ selama 10 menit. Produk PCR dipisahkan dengan elektroforesis DNA (Mupid-EXu) menggunakan gel agarosa 1\% bersama dengan marker DNA 2000 bp (TaKaRa), diwarnai dengan etidium bromida (Sigma Aldrich, USA), dan divisualisasikan dengan Geldoc UV transilluminator (Biometra-Herolab UVT-20M). Sekuensing 16S rRNA dilakukan di $1^{\text {st }}$ Base, Singapura. Hasil sekuen kemudian dicari kemiripannya dengan gen $16 S$ yang ada di situs NCBI menggunakan BLAST N/Alat Pencarian Alignment Dasar Lokal (Altschul, Gish, Miller, Myers, \& Lipman, 1990), kemudian disusun menggunakan program Clustal $W$ (Higgins, Thompson, \& Gibson, 1996). Analisa neighbor-joining mid-point (Kim, 1993) dilakukan dengan perangkat lunak MEGA7 (Kumar, Stecher, \& Tamura, 2016).

\section{HASIL DAN PEMBAHASAN}

\section{Bakteri Penghasil Agarase}

Terdapat 16 strain dari 45 isolat yang mempunyai aktivitas agarase yang ditunjukkan dengan terbentuknya zona bening di sekitar koloni pada media padat air laut setelah inkubasi 24 jam (Gambar 2). Dari hasil pengamatan, terdapat 3 jenis zona bening yang terbentuk pada media padat (Tabel 1). Pada skala 1-5, tipe 1 menunjukkan zona bening bergradasi dimana zona bening di sekitar koloni dengan tingkat transparansi 5 sedangkan di bagian luar 3 . Tipe kedua adalah zona bening dengan tingkat transparansi skala 3 , sedangkan yang terakhir adalah dengan tingkat transparansi level 1. Perbedaan tersebut kemungkinan disebabkan oleh keragaman jenis agarase yang dihasilkan oleh masing-masing isolat.

Skrining bakteri laut untuk strain penghasil agarase dilakukan dengan media selektif air laut. Media ini digunakan untuk menyeleksi bakteri yang tumbuh pada media. Dengan terbatasnya nutrisi yang tersedia sebagai komponen media, sebagian besar bakteri yang tumbuh diharapkan bakteri penghasil agarase.
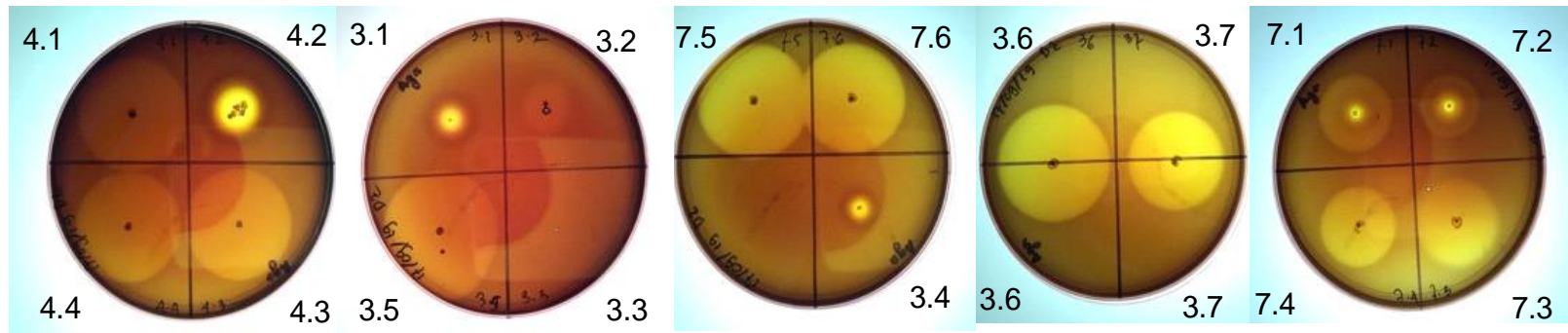

Gambar 2. Zona bening yang dibentuk oleh 16 bakteri penghasil agarase (angka merupakan kode isolat) pada MAL padat setelah inkubasi 24 jam. Pewarnaan dilakukan dengan larutan lugol 10\%.

Figure 2. The clear zone formed by 16 agarase-producing bacteria (the numbers are the isolate codes) on solid marine medium after 24-hours incubation. The staining was carried out with a $10 \%$ lugol solution.

Tabel 1. Tipe zona bening yang dibentuk oleh bakteri penghasil agarase pada media padat air laut Table 1. Type of clear zone formed by agarase-producing bacteria on sea water solid medium

\begin{tabular}{ccc}
$\begin{array}{l}\text { Tipe zona bening/ } \\
\text { Type of clear zone }\end{array}$ & $\begin{array}{c}\text { Transparansi (skala 1-5)/ } \\
\text { Transparancy (scale 1-5) }\end{array}$ & Isolat/lsolate \\
\hline I & 5 & BC-3.1; BC-3.4; BC-4.2; BC-7.1; BC 7.2 \\
II & 3 & BC-7.5; BC-7.6; BC-3.6; BC-3.7; BC-7.4; BC-7.3 \\
III & 1 & BC-4.1; BC-4.3; BC-4.4; BC-3.5; BC-3.2
\end{tabular}


Ketersediaan agar sebagai substrat diharapkan dapat menginduksi gen agarase dari bakteri yang kemudian akan mengekspresikan enzim untuk mendegradasi agar (Kluge, Terfehr, \& Kück, 2018; Smith \& Grula, 1983). Dengan kata lain, bakteri yang mempunyai gen agarase berpeluang yang lebih besar untuk tumbuh dengan baik pada media selektif ini. Ada tiga jenis zona bening yang ditunjukkan oleh isolat pada medium padat, seperti disajikan pada Gambar 2. Jenis zona bening yang sama ditunjukkan oleh isolat BC-3.1, BC4.2, BC-3.4, BC-7.1, dan BC-7.2 yang berada pada kelompok yang sama seperti yang ditunjukkan pada pohon filogenetik (Gambar 4). Hal ini dapat menjelaskan mengapa mereka diduga menghasilkan jenis agarase yang sama.

\section{Amplifikasi Gene 16S rRNA dan Analisa Kemiripan}

Gen 16S rRNA dari semua isolat penghasil agarase berhasil diamplifikasi dan menunjukkan pita DNA berukuran \pm 1.500 bp pada gel agarosa $1 \%$ (Gambar 3). Tiga referensi strain teratas berdasarkan hasil BLAST $\mathrm{N}$ yang menunjukkan persentase kemiripan dengan isolat penghasil agarase disajikan pada Tabel 2. Beberapa isolat memiliki kemiripan referensi yang sama pada data base, seperti BC-3.5 dan BC-3.6 serta BC-4.1, BC-4.3, dan BC-7.5. Hal ini kemungkinan disebabkan isolat-isolat tersebut merupakan jenis yang sama dan akan dikonfirmasi pada analisis pohon filogenetik. Pohon filogenetik dibuat berdasarkan urutan gen 16S rRNA dari 16 bakteri penghasil agarase yang dibandingkan dengan sekuens bakteri referensi pada bank data NCBI (Gambar 4). Dari neighborjoining tree bisa diketahui bahwa 16 bakteri penghasil agarase yang diisolasi dari sedimen laut Pulau Bara Caddi termasuk dalam empat genera dan memiliki kesamaan dengan enam spesies yaitu Alteromonas macleodii, Vibrio neocaledonicus, Vibrio parahaemolyticus, Vibrio alginolyticus, Marinobacter hydrocarbonoclasticus, dan Salinivibrio budaii. Vibrio merupakan genus dominan yang diwakili oleh 10 isolat, diikuti oleh Alteromonas dengan 4 isolat, sedangkan Salinivibrio dan Marinobacterium masingmasing 1 isolat.

Vibrio adalah bakteri yang umum ditemukan di sedimen laut dan muara. Terdapat tiga spesies Vibrio sp. yang menunjukkan kemiripan tertinggi dengan isolat Bara Caddi, yaitu V. neocaledonicus (BC-3.2, BC-4.1, BC 4.3 dan BC-7.5), V. parahaemolyticus (BC-3.5 dan $\mathrm{BC}-3.6)$, dan $V$. alginolyticus (BC-4.4). $V$. parahaemolyticus dan $V$. alginolyticus telah dilaporkan sebagai bakteri patogen (Lee, 1995; Schmidt, Chmel, \& Cobbs, 1979), sehingga Vibrio neocaledonicus merupakan kandidat isolat yang berpontensi untuk diteliti lebih lanjut. Selain bukan bakteri patogen, bakteri ini sudah dilaporkan memiliki potensi sebagai penghambat proses korosi (Moradi, Song, \& Tao, 2015; Moradi, Song, \& Xiao, 2018; Moradi, Xiao, \& Song, 2015), penghasil exopolysaccharide (Chalkiadakis et al., 2013), dan menunjukan beberapa aktivitas biologis (GómezBetancur et al., 2019).

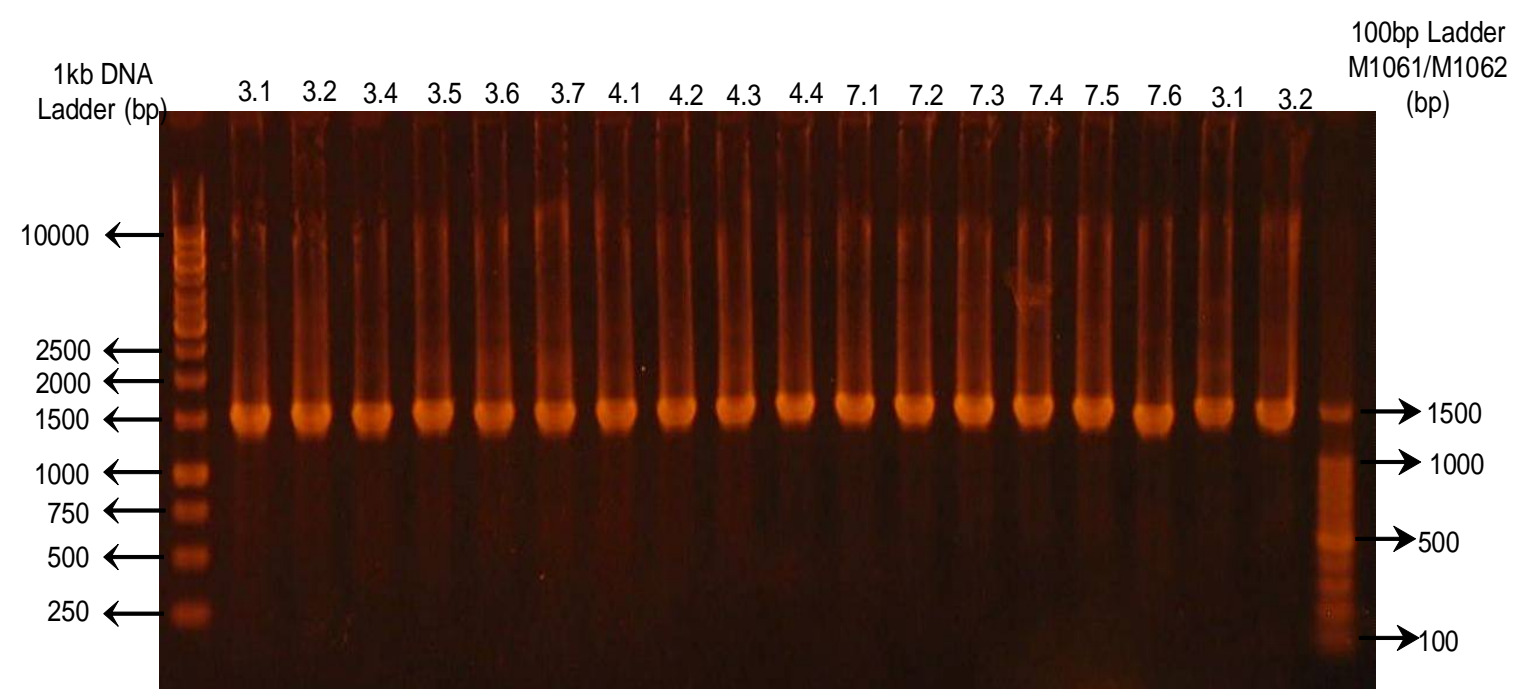

Gambar 3.Hasil PCR 16S rRNA dari 16 bakteri penghasil agarase yang diisolasi dari sediment laut (M=Marker $2,000 \mathrm{bp})$

Figure 3. PCR amplified 16S rRNA of 16 agarase-producing bacteria isolated from marine sediment ( $M=$ Marker 2,000 bp) 
Tabel 2. Kode dan accession number NCBI bakteri penghasil agarase yang diisolasi dari Pulau Bara Caddi dan hasil dari BLAST N (strain referensi, accession number, dan persen kemiripan isolat Bara Caddi)

Table 2. Code and NCBI accession number of agarase-producing bacteria isolated from Bara Caddi Island and the result of BLASTN (reference strain, accession number, and percent of similarity with the Bara Caddi isolates)

\begin{tabular}{|c|c|c|c|c|c|}
\hline $\begin{array}{l}\text { Kode } \\
\text { Is olat/ } \\
\text { Isolate } \\
\text { Code }\end{array}$ & $\begin{array}{c}\text { Aktivitas } \\
\text { agarase (Indek } \\
\text { agarolitik,IA)/ } \\
\text { Agarase } \\
\text { Activity } \\
\text { (Carbolitic } \\
\text { Index, AI) }\end{array}$ & $\begin{array}{c}\text { Nomor } \\
\text { Aksesi/ } \\
\text { Accession } \\
\text { number }\end{array}$ & $\begin{array}{c}\text { Strain Rujukan/ } \\
\text { Reference strain (NCBI) }\end{array}$ & $\begin{array}{c}\text { Aksesi dari } \\
\text { strain Rujukan/ } \\
\text { Accesion } \\
\text { number of } \\
\text { reference strain }\end{array}$ & $\begin{array}{c}\text { Kemirip/ } \\
\text { Similarity } \\
(\%)\end{array}$ \\
\hline \multirow[t]{3}{*}{ BC-3.1 } & 10 & MT325874 & Alteromonas macleodii ATCC 27126 , & CP003841.1 & $99.72 \%$ \\
\hline & & & Uncultured Alteromonas sp. clone K4S167 & JN177693.1 & $99.72 \%$ \\
\hline & & & Bacterium 3D801 & JF411517.1 & $99.72 \%$ \\
\hline \multirow[t]{3}{*}{ BC-3.2 } & 5.5 & МT325875 & Vibrio neocaledonicus strain CGJ02-2 & СР032213.1 & $99.72 \%$ \\
\hline & & & Vibrio sp. strain S5-4-14 & MK720198.1 & $99.72 \%$ \\
\hline & & & Vibrio sp. strain 201709 CJKYOP-47 & MH093804.1 & $99.72 \%$ \\
\hline \multirow[t]{3}{*}{ BC-3.4 } & 8 & МТ325876 & Uncultured bacterium clone N8_12_C_6D_31 & KF271113.1 & $99.93 \%$ \\
\hline & & & Alteromonas macleodii ATCC 27126 & CP003841.1 & $99.93 \%$ \\
\hline & & & Uncultured Alteromonas sp. clone K4S167 & JN177693.1 & $99.93 \%$ \\
\hline \multirow[t]{3}{*}{ BC-3.5 } & 13.5 & Мा325877 & Vibrio parahaemolyticus strain FORC_072 & CP023473.1 & $100.00 \%$ \\
\hline & & & Vibrio parahaemolyticus O1:K33 str. CDC_K4557 & CP006008.1 & $100.00 \%$ \\
\hline & & & Vibrio parahaemolyticus strain FORC_071 & CP023485.1 & $99.93 \%$ \\
\hline \multirow[t]{3}{*}{ BC-3.6 } & 12.5 & МТ325878 & Vibrio parahaemolyticus strain FORC_072 & CP023473.1 & $100.00 \%$ \\
\hline & & & Vibrio parahaemolyticus O1:K33 str. CDC_K4557 & CP006008.1 & $100.00 \%$ \\
\hline & & & Vibrio parahaemolyticus strain FORC_071 & CP023485.1 & $99.93 \%$ \\
\hline \multirow[t]{3}{*}{ BC-3.7 } & 10.75 & МТ325879 & Vibrio sp. strain S5-4-14 & MK720198.1 & $99.86 \%$ \\
\hline & & & Vibrio sp. strain 201709CJKYOP-47 & MH093804.1 & $99.86 \%$ \\
\hline & & & Vibrio alginolyticus strain SC9 & MK308586.1 & $99.86 \%$ \\
\hline \multirow[t]{3}{*}{ BC- 4.1} & 12.5 & МТ325880 & Vibrio neocaledonicus strain CGJ02-2 & CP032213.1 & $100.00 \%$ \\
\hline & & & Vibrio alginolyticus strain FDAARGOS_114 & CP014045.1 & $100.00 \%$ \\
\hline & & & Bacterium JSB522 & KJ457311.1 & $100.00 \%$ \\
\hline \multirow[t]{3}{*}{ BC-4.2 } & 6 & МТ325881 & Alteromonas sp. E407-6 & FJ169967.1 & $100.00 \%$ \\
\hline & & & Alteromonas macleodii strain HOT1A3 & CP012202.1 & $99.93 \%$ \\
\hline & & & Alteromonas sp. E407-4 & FJ169965.1 & $99.93 \%$ \\
\hline \multirow[t]{3}{*}{ BC-4.3 } & 11.5 & МТ325882 & Vibrio neocaledonicus strain CGJ02-2 & СР032213.1 & $99.93 \%$ \\
\hline & & & Vibrio alginolyticus strain FDAARGOS & CP014045.1 & $99.93 \%$ \\
\hline & & & Vibrio parahaemolyticus strain $\mathrm{CHN}-4$ & KR347178.1 & $99.93 \%$ \\
\hline \multirow[t]{3}{*}{ BC-4.4 } & 11.5 & МТ325883 & Vibrio alginolyticus strain 2013V-1302 & CP035700.1 & $99.86 \%$ \\
\hline & & & Vibrio neocaledonicus strain CGJ02-2 & СР032213.1 & $99.86 \%$ \\
\hline & & & Vibrio alginolyticus strain FDAARGOS_108 & CP014053.1 & $99.86 \%$ \\
\hline \multirow[t]{3}{*}{ BC-7.1 } & 6.2 & MT325884 & Alteromonas macleodii strain Te101 & CP018321.1 & $100.00 \%$ \\
\hline & & & Alteromonas sp. strain JLT1510 & KX989248.1 & $100.00 \%$ \\
\hline & & & Alteromonas sp. strain InS-267 & MF359500.1 & $100.00 \%$ \\
\hline \multirow[t]{3}{*}{ BC-7.2 } & 5.8 & МТ325885 & Alteromonas macleodii strain Te101 & CP018321.1 & $100.00 \%$ \\
\hline & & & Alteromonas macleodii strain KS62 & KY608081.1 & $100.00 \%$ \\
\hline & & & Uncultured Proteobacterium & KM018571.1 & $100.00 \%$ \\
\hline \multirow[t]{3}{*}{ BC-7.3 } & 6.8 & МТ325886 & Salinivibrio sp. YCSC6 & CP039516.1 & $99.93 \%$ \\
\hline & & & Salinivibrio budaii & AB617564.1 & $99.93 \%$ \\
\hline & & & Salinivibrio sp. strain M318 & MN262232.1 & $99.86 \%$ \\
\hline \multirow[t]{3}{*}{ BC-7.4 } & 6.8 & МТ325887 & Marinobacter hydrocarbonoclasticus strain ss 12 & JN160753.1 & $99.93 \%$ \\
\hline & & & Marinobacter hydrocarbonoclasticus strain ss 11 & JN160752.1 & $99.93 \%$ \\
\hline & & & Marinobacter hydrocarbonoclasticus strain ss 10 & JN160751.1 & $99.93 \%$ \\
\hline \multirow[t]{3}{*}{ BC-7.5 } & 12.8 & МТ325888 & Vibrio neocaledonicus strain CGJ02-2 & СР032213.1 & $99.93 \%$ \\
\hline & & & Vibrio alginolyticus strain FDAARGOS_114 & CP014045.1 & $99.93 \%$ \\
\hline & & & Vibrio parahaemolyticus strain $\mathrm{CHN}-4$ & KR347178.1 & $99.93 \%$ \\
\hline \multirow[t]{3}{*}{ BC-7.6 } & 12.6 & МТ325889 & Vibrio sp. strain S5-4-14 & MK720198.1 & $99.93 \%$ \\
\hline & & & Vibrio sp. strain 201709 CJKYOP-47 & MH093804.1 & $99.93 \%$ \\
\hline & & & Vibrio parahaemolyticus strain FORC_072 & CP023473.1 & $99.93 \%$ \\
\hline
\end{tabular}




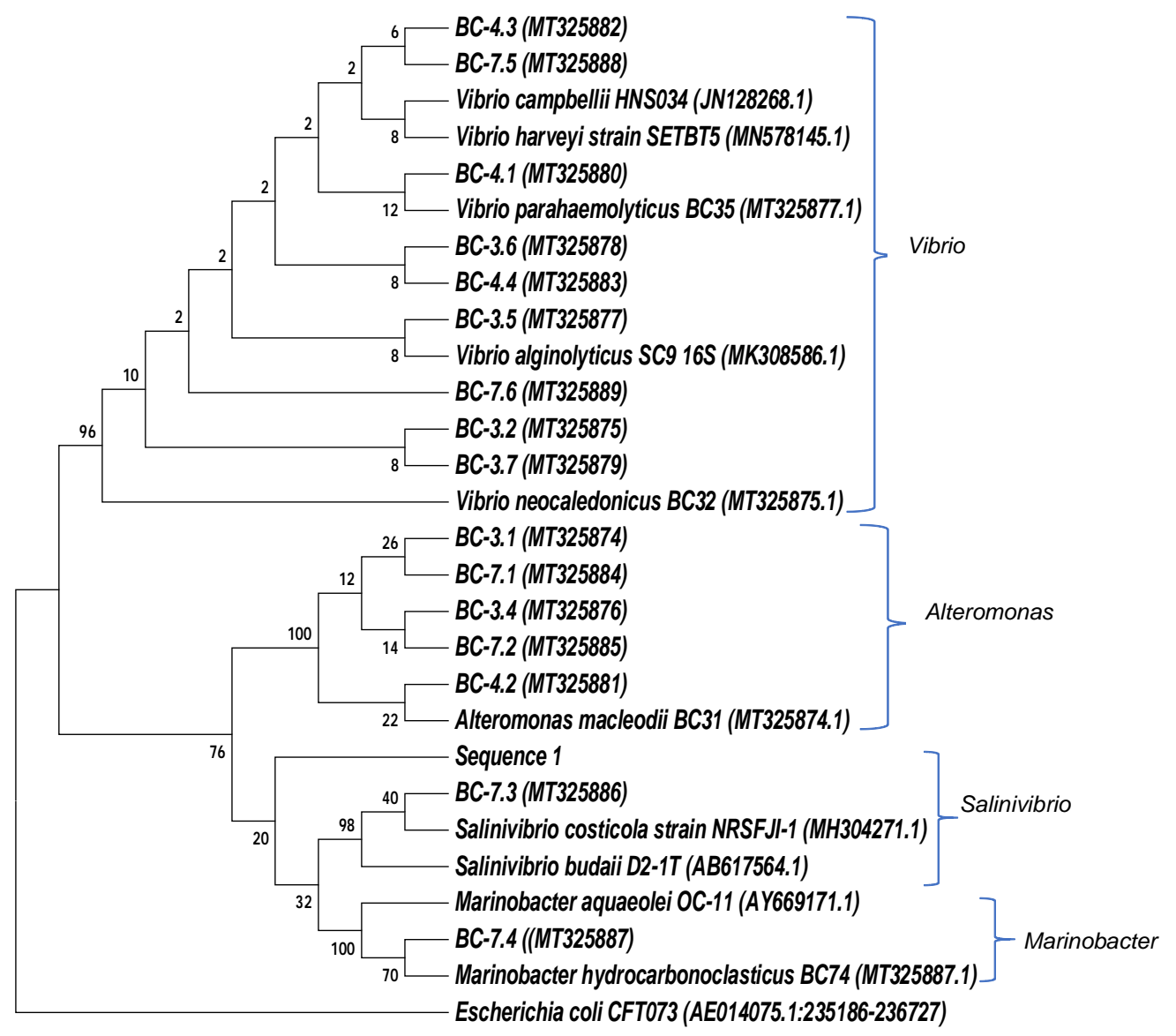

Gambar 4. Neighbor-joining phylogenetic tree (bootstrap =1000) dibuat dengan MEGA7 yang menunjukkan hubungan bakteri penghasil agarase yang diisolasi dari sedimen laut dan strain yang ada di NCBI GenBank berdasarkan analisis urutan gen 16S rRNA

Figure 4. Neighbor-joining phylogenetic tree (bootstrap = 1000) constructed by MEGA7 showing the relationship of agarase-producing bacteria isolated from marine sediment and the strains presented in GenBank based on 16S rRNA gene analysis

Isolat potensial lain yang ditemukan adalah $A$. macleodii dengan kemiripan $99-100 \%$. Isolat ini adalah satu-satunya spesies diantara isolat hasil skrining yang pernah dilaporkan menghasilkan agarase (Chiura, \& Kita-Tsukamoto, 2000). A. macleodiiadalah bakteri laut aerobik yang pertama kali dideskripsikan dan dipelajari pada tahun 1972. Penelitian yang menggunakan beberapa sampel DNA dari seluruh dunia menunjukkan bahwa fraksi DNA A. macleodii mirip dengan fraksi DNA populasi bakteri yang berasosiasi dengan partikel atau agregat $(0,2 \mathrm{~mm}$ filter). Populasi bakteri ini hidup di perairan tropis dengan suhu rata-rata di atas $10^{\circ} \mathrm{C}$ (López-Pérez et al., 2012). A. macleodii dilaporkan memiliki cluster gen PKS-NRPS untuk antitumor dan antibiotik (Mizuno et al., 2013). Baru-baru ini spesies tersebut dilaporkan menghasilkan Vesicles membrane (Naval \& Chandra, 2019), yaitu nanopartikel yang terdiri atas membran lipid yang diproduksi oleh bakteri dengan fungsi biologis yang beragam dan menunjukkan potensi besar untuk aplikasi di berbagai bidang (Nagakubo, Nomura, \& Toyofuku, 2020). Analisa proteomik terhadap Vesicles membrane yang dihasilkan oleh $A$. macleodii menunjukan bahwa membran ini terdiri atas berbagai enzim pengurai karbohidrat, protease, sulfatase, dan hidrolase lainnya (Naval \& Chandra, 2019).

Hasil analisis urutan gen $16 S$ menunjukkan bahwa BC-7.3 mempunyai kemiripan dengan Salinivibrio sp. YCSC6 dan S. budaii dengan tingkat kemiripan yang sama, yaitu 99,93\%. Genus Salinivibrio dikelompokkan ke dalam kelas Gammaproteobacteria, famili Vibrionaceae dan termasuk dalam kelompok halofilk moderat yaitu bakteri yang dapat tumbuh pada kadar $\mathrm{NaCl} 0-25 \%$ dengan optimum kadar $\mathrm{NaCl}$ untuk pertumbuhan adalah 7,5\%. Kelompok bakteri ini dapat tumbuh pada kisaran suhu dan $\mathrm{pH}$ yang luas yaitu 
suhu $17-55^{\circ} \mathrm{C}$ dan pH 5-11 (Gorriti et al., 2014; Huang et al., 2000). Genus ini ditemukan bersama bakteri halofilik lain dari sampel tanah hypersaline di Colombian Caribbean dengan aktifitas bioremediasi terhadap kontaminasi perklorat (Acevedo-Barrios, Bertel-Sevilla, Alonso-Molina, \& Olivero-Verbel, 2019). S. budaii dilaporkan pertama kali tahun 2007 ke NCBI sebagai spesies baru yang diisolasi dari kolam garam di pantai barat Taiwan (NCBI, https:// www.ncbi.nlm.nih.gov/Taxonomy/Browser/ wwwtax.cgi?id=444168). Sampai saat ini, belum ada informasi mengenai potensi $S$. budaii sehingga menjadikannya sangat menarik untuk dieksplorasi lebih lanjut, terutama karena pada penelitian ini menunjukkan kemampuan untuk menghasilkan agarase.

M. hydrocarbonoclasticus yang menunjukkan tingkat kemiripan 99,93\% dengan BC-7.4 dilaporkan sebagai bakteri pendegradasi hidrokarbon (Mounier et al., 2014; Striebich et al., 2014). Spesies ini mempunyai kemampuan mereduksi senyawa nitrat $\left(\mathrm{NO}_{3}{ }^{-}\right)$menjadi senyawa nitrogen bebas $\left(\mathrm{N}_{2}\right)$ dan mendegradasi senyawa antibiotik (Ruan et al., 2020). Penghasil nitric oxide reductase (Carreira, dos Santos, Pauleta, \& Moura, 2020; Gomes et al., 2019), M. hydrocarbonoclasticus adalah bakteri laut gram negatif yang tidak membentuk spora dan tumbuh optimum pada kadar garam $0,6 \mathrm{M}$ suhu $32^{\circ} \mathrm{C}$ (Gauthier et al., 1992). Tidak ada laporan yang menyebutkan bahwa bakteri ini menghasilkan agarase.

Penelitian lebih lanjut diperlukan untuk mengetahui karakteristik agarase yang dihasilkan oleh semua isolat, terutama yang belum pernah dilaporkan sebagai penghasil agarase dan bakteri non-patogen. Ada kemungkinan bahwa agarase yang dihasilkan oleh isolat tersebut merupakan jenis agarase baru dengan sifat yang unik.

\section{KESIMPULAN}

Berdasarkan hasil penelitian diperoleh 16 isolat yang positif menghasilkan agarase berdasarkan zona bening. Zona bening yang terbentuk tidak hanya bisa dibedakan dari indeks karbolitik, tetapi juga dari tingkat transparansi yang kemungkinan disebabkan oleh perbedaan jenis agarase yang dihasilkan oleh masingmasing isolat. Hal ini juga didukung oleh hasil identifikasi dimana isolat yang berada di grup yang sama, membentuk zona bening dengan karakter yang sama, baik berdasarkan indeks karbolitik maupun tingkat transparansinya. Hasil identifikasi secara molekuler memperlihatkan bahwa isolat-isolat yang diperoleh terdiri atas 4 genus, yaitu Vibrio, Alteromonas, Marinobacter, dan Salinivibrio. Dari 16 isolat yang diidentifikasi, $A$. macleodii merupakan satu-satunya spesies yang pernah dilaporkan menghasilkan agarase. Ditemukannya bakteri-bakteri penghasil agarase yang belum pernah dilaporkan sebelumnya membuka peluang untuk menemukan agarase baru sehingga penilitian lebih lanjut diperlukan untuk mengetahui karakteristik agarase yang dihasilkan oleh isolat-isolat ini, khususnya isolat non-patogen.

\section{UCAPAN TERIMA KASIH}

Penelitian ini dibiayai oleh Anggaran Pendapatan dan Belanja Negara (APBN) yang dikelola oleh Balai Besar Riset Pengolahan Produk dan Bioteknologi Kelautan dan Perikanan (BBRPPB-KP), Badan Riset dan Sumberdaya Manusia (BRSDM), Kementerian Kelautan dan Perikanan (KKP). Penelitian ini juga merupakan hasil kerjasama BBRPPB-KP dengan Fakultas IImu Kelautan dan Perikanan, Universitas Diponegoro.

\section{DAFTAR PUSTAKA}

Acevedo-Barrios, R., Bertel-Sevilla, A., Alonso-Molina, J., \& Olivero-Verbel, J. (2019). Perchlorate-reducing bacteria from hypersaline soils of the Colombian Caribbean. International Journal of Microbiology. doi: 10.1155/2019/6981865

Altschul, S. F., Gish, W., Miller, W., Myers, E. W., \& Lipman, D. J. (1990). Basic local alignment search tool. Journal of Molecular Biology, 215(3), 403-410. doi: 10.1016/S0022-2836(05)80360-2

Aravena, P., Pulgar, R., Ortiz-Severín, J., Maza, F., Gaete, A., Martínez, S., ... Cambiazo, V. (2020). PCR-RFLP Detection and genogroup identification of Piscirickettsia salmonis in field samples. Pathogens, 9(5), 358. doi: 10.3390/pathogens9050358

Asagabaldan, M. A., Bedoux, G., \& Bourgougnon, N. (2019). Bacterial isolates from bryozoan Pleurocodonellina sp.: diversity and antimicrobial potential against pathogenic bacteria. Biodiversitas, 20(9), 2528-2535. doi: 10.13057/biodiv/d200914

Ayuningrum, D., Kristiana, R., Asagabaldan, M. A., Sabdono, A., Radjasa, O. K., Nuryadi, H., \& Trianto, A. (2017). Isolation, characterisation and antagonistic activity of bacteria symbionts hardcoral Pavona sp. isolated from Panjang Island, Jepara against infectious multi-drug resistant (MDR) bacteria. IOP Conference Series: Earth and Environmental Science, 55(1), 12029. doi: 10.1088/1755-1315/55/ $1 / 012029$

Ayuningrum, D., Kristiana, R., Nisa, A. A., ... \& Radjasa, S. K. (2019). Bacteria associated with tunicate, Polycarpa aurata, from Lease Sea, Maluku, Indonesia exhibiting anti-multidrug resistant bacteria. Biodiversitas, 20(4), 956-964. doi: 10.13057/biodiv/d200404 
Carreira, C., dos Santos, M. M. C., Pauleta, S. R., \& Moura, I. (2020). Proton-coupled electron transfer mechanisms of the copper centres of nitrous oxide reductase from Marinobacter hydrocarbonoclasticus - an electrochemical study. Bioelectrochemistry, 133, 107483. doi: 10.1016/j.bioelechem.2020.107483

Chalkiadakis, E., Dufourcq, R., Schmitt, S., Brandily, C., Kervarec, N., Coatanea, D., ... Simon-Colin, C. (2013). Partial characterization of an exopolysaccharide secreted by a marine bacterium, Vibrio neocaledonicus sp. nov., from New Caledonia. Journal of Applied Microbiology, 114(6), 1702-1712. doi: 10.1111/jam.12184

Cheng, T. H., Ismail, N., Kamaruding, N., Saidin, J., \& Danish-Daniel, M. (2020). Industrial enzymesproducing marine bacteria from marine resources. Biotechnology Reports, 27, e00482. doi: 10.1016/ j.btre.2020.e00482

Chi, W. J., Lee, C. R., Dugerjonjuu, S., Park, J. S., Kang, D. K., \& Hong, S.K. (2015). Biochemical characterization of a novel iron-dependent GH16 $\beta$ agarase, AgaH92, from an agarolytic bacterium Pseudoalteromonas sp. H9. FEMS Microbiology Letters, 362(7). doi: 10.1093/femsle/fnv035

Chiura, H. X., \& Kita-Tsukamoto, K. (2000). Purification and characterisation of a novel agarase secreted by a marine bacterium, Pseudoalteromonas sp. strain CKT1. Microbes and Environments, 15(1), 11-22. doi: 10.1264/jsme2.2000.11

Dipakkore, S., Reddy, C. R. K., \& Jha, B. (2005). Production and seeding of protoplasts of Porphyra okhaensis (Bangiales, Rhodophyta) in laboratory culture. Journal of Applied Phycology, 17(4), 331337. doi:10.1007/s10811-005-7291-8

Farahat, M. (2019). Enhanced anti-oxidant activity of neoagarooligosaccharides produced by $\beta$-agarase derived from Aquimarina agarilytica NI125. Novel Research in Microbiology Journal, 3(6), 511-525. doi: 10.21608/nrmj.2019.66744

Gauthier, M. J., Lafay, B., Christen, R., Fernandez, L., Acquaviva, M., Bonin, P., \& Bertrand, J. C. (1992). Marinobacter hydrocarbonoclasticus gen. nov., sp. nov., a new, extremely halotolerant, hydrocarbondegrading marine bacterium. Microbiology Society, 42(4), 568-576.

Giddings, L.-A., \& Newman, D. J. (2015). Bioactive compounds from marine extremophiles BT bioactive compounds from marine extremophiles (L.A. Giddings \& D. J. Newman, Eds.). Cham: Springer International Publishing. doi: 10.1007/978-3-31914361-3_1

Gomes, F. O., Maia, L. B., Cordas, C., Moura, I., DelerueMatos, C., Moura, J. J. G., \& Morais, S. (2019). Electroanalytical characterization of the direct Marinobacter hydrocarbonoclasticus nitric oxide reductase-catalysed nitric oxide and dioxygen reduction. Bioelectrochemistry, 125, 8-14. doi: 10.1016/j.bioelechem.2018.08.005

Gómez-Betancur, I., Zhao, J., Tan, L., Chen, C., Yu, G., Rey-Suárez, P., \& Preciado, L. (2019). Bioactive compounds isolated from marine bacterium Vibrio neocaledonicus and their enzyme inhibitory activities. Marine Drugs, 17(7), 401.

Gorriti, M. F., Dias, G. M., Chimetto, L. A., Trindade-Silva, A. E., Silva, B. S., Mesquita, M. M. A., ... Thompson, F. L. (2014). Genomic and phenotypic attributes of novel Salinivibrios from stromatolites, sediment and water from a high altitude lake. BMC Genomics, 15(1), 473. doi: 10.1186/1471-2164-15-473

Haghparast, R. J., Moghanlou, K. S., Mohseni, M., \& Imani, A. (2019). Effect of dietary soybean lecithin on fish performance, hemato-immunological parameters, lipid biochemistry, antioxidant status, digestive enzymes activity and intestinal histomorphometry of pre-spawning Caspian brown trout (Salmo trutta caspius). Fish \& Shellfish Immunology, 91, 50-57. doi: 10.1016/j.fsi.2019.05.022

Hassairi, I., Ben Amar, R., Nonus, M., \& Gupta, B. B. (2001). Production and separation of $\beta$-agarase from Altermonas agarlyticus strain GJ1B. Bioresource Technology, 79(1), 47-51. doi: 10.1016/S09608524(01)00037-2

Higgins, D. G., Thompson, J. D., \& Gibson, T. J. (1996). Using CLUSTAL for multiple sequence alignments. Methods in enzymology, 266, 383-402. doi: 10.1016/ s0076-6879(96)66024-8

Hong, S. J., Lee, J. H., Kim, E. J., Yang, H. J., Park, J.-S., \& Hong, S. K. (2017). Anti-obesity and anti-diabetic effect of neoagarooligosaccharides on high-fat dietinduced obesity in mice. Marine Drugs,15. doi: $10.3390 / \mathrm{md} 15040090$

Hou, Y., Chen, X., Chan, Z., \& Zeng, R. (2015). Expression and characterization of a thermostable and $\mathrm{pH}$-stable $\beta$-agarase encoded by a new gene from Flammeovirga pacifica WPAGA1. Process Biochemistry, 50(7), 1068-1075. doi: 10.1016/ j.procbio.2015.04.005

Hu, Z., Lin, B., Xu, Y., Zhong, M. Q., \& Liu, G. (2009). Production and purification of agarase from a marine agarolytic bacterium Agarivorans sp. HZ105. Journal of Applied Microbiology, 106(1), 181-190.

Huang, C. Y., Garcia, J. L., Patel, B. K. C., Cayol, J. L., Baresi, L., \& Mah, R. A. (2000). Salinivibrio costicola subsp. vallismortis subsp. nov., a halotolerant facultative anaerobe from Death Valley, and emended description of Salinivibrio costicola. International Journal of Systematic and Evolutionary Microbiology, 50(2), 615-622. doi: 10.1099/00207713-50-2-615

Javahery, S., Noori, A., \& Hoseinifar, S. H. (2019). Growth performance, immune response, and digestive enzyme activity in Pacific white shrimp, Penaeus vannamei Boone, 1931, fed dietary microbial lysozyme. Fish \& Shellfish Immunology, 92, 528-535. https://doi.org/https://doi.org/10.1016/ j.fsi.2019.06.049

Jensen, A. (1993). Present and future needs for algae and algal products. In A. R. O. Chapman, M. T. Brown, \& M. Lahaye (Eds.), Fourteenth International Seaweed Symposium (pp. 15-23). Dordrecht: Springer Netherlands. 
Jung, S., Lee, C.-R., Chi, W.-J., Bae, C.-H., \& Hong, S.-K. (2017). Biochemical characterization of a novel coldadapted GH39 â-agarase, AgaJ9, from an agardegrading marine bacterium Gayadomonas joobiniege G7. Applied Microbiology and Biotechnology, 101(5), 1965-1974. doi: 10.1007/ s00253-016-7951-4

Kang, D. R., Yoon, G. Y., Cho, J., Lee, S. J., Lee, S. J., Park, H. J.,... Jung, I. D. (2017). Neoagarooligosaccharides prevent septic shock by modulating A20-and cyclooxygenase-2-mediated interleukin-10 secretion in a septic-shock mouse model. Biochemical and Biophysical Research Communications, 486(4), 9981004. doi: 10.1016/j.bbrc.2017.03.152

Kim, J. (1993). Improving the Accuracy of Phylogenetic Estimation by Combining Different Methods. Systematic Biology, 42(3), 331-340. https://doi.org/ 10.1093/sysbio/42.3.331

Kim, J. H., Yun, E. J., Yu, S., Kim, K. H., \& Kang, N. J. (2017). Different levels of skin whitening activity among 3,6-anhydro-L-galactose, agarooligosaccharides, and neoagarooligosaccharides. Marine Drugs, Vol. 15. doi: $10.3390 / \mathrm{md} 15100321$

Kluge, J., Terfehr, D., \& Kück, U. (2018). Inducible promoters and functional genomic approaches for the genetic engineering of filamentous fungi. Applied Microbiology and Biotechnology, 102(15), 63576372. doi: 10.1007/s00253-018-9115-1

Kristiana, R., Ayuningrum, D., Yohanna, M., Dirgantara, D., Hanafi, M., Radjasa, O. K., ... Sabdono, A. (2019a). Characterization and identification of antibacterial compound from Pseudoalteromonas piscicida associated with Chromodoris lochi. AIP Conference Proceedings, 2120(1), 80008. doi: doi.org/10.1063/ 1.5115746

Kristiana, R., Sibero, M. T., Farisa, M. Y., Ayuningrum, D., Dirgantara, D., Hanafi, M., ... Trianto, A. (2019b). Antibacterial potential of nudibranch-associated bacteria from Saparua and Nusa Laut Islands, Indonesia. Biodiversitas, 20(7), 1811-1819. doi: $10.13057 /$ biodiv/d200704

Kumar, S., Stecher, G., \& Tamura, K. (2016). MEGA7: molecular evolutionary genetics analysis version 7.0 for bigger datasets. Molecular Biology and Evolution, 33(7), 1870-1874. doi: 10.1093/molbev/msw054

Lee, K. K. (1995). Pathogenesis studies on Vibrio alginolyticus in the grouper, Epinephelus malabaricus, Bloch et Schneider. Microbial pathogenesis, 19(1), 39-48.

Liang, Y., Ma, X., Zhang, L., Li, F., Liu, Z., \& Mao, X. (2017). Biochemical characterization and substrate degradation mode of a novel exotype $\beta$-agarase from Agarivorans gilvus WH0801. Journal of Agricultural and Food Chemistry, 65(36), 7982-7988. doi: $10.1021 /$ acs.jafc. $7 b 01533$

Lin, B., Liu, Y., Lu, G., Zhao, M., \& Hu, Z. (2017). An agarase of glycoside hydrolase family 16 from marine bacterium Aquimarina agarilytica ZC1. FEMS Microbiology Letters, 364(4). doi: 10.1093/femsle/ fnx012
López-Pérez, M., Gonzaga, A., Martin-Cuadrado, A. B., Onyshchenko, O., Ghavidel, A., Ghai, R., \& RodriguezValera, F. (2012). Genomes of surface isolates of Alteromonas macleodii: the life of a widespread marine opportunistic copiotroph. Scientific Reports, 2(1), 1-11.

Mizuno, C. M., Kimes, N. E., López-Pérez, M., Ausó, E., Rodriguez-Valera, F., \& Ghai, R. (2013). A hybrid NRPS-PKS gene cluster related to the bleomycin family of antitumor antibiotics in Alteromonas macleodii strains. PloS One, 8(9), e76021-e76021. doi: 10.1371/journal.pone.0076021

Moradi, M., Song, Z., \& Tao, X. (2015). Introducing a novel bacterium, Vibrio neocaledonicus sp., with the highest corrosion inhibition efficiency. Electrochemistry Communications, 51, 64-68. doi: 10.1016/j.elecom.2014.12.007

Moradi, M., Song, Z., \& Xiao, T. (2018). Exopolysaccharide produced by Vibrio neocaledonicus $\mathrm{sp}$. as a green corrosion inhibitor: Production and structural characterization. Journal of Materials Science \& Technology, 34(12), 2447-2457. doi: 10.1016/ j.jmst.2018.05.019

Moradi, M., Xiao, T., \& Song, Z. (2015). Investigation of corrosion inhibitory process of marine Vibrio neocaledonicus sp. bacterium for carbon steel. Corrosion Science, 100, 186-193. doi: 10.1016/ j.corsci.2015.07.030

Mounier, J., Camus, A., Mitteau, I., Vaysse, P. J., Goulas, P., Grimaud, R., \& Sivadon, P. (2014). The marine bacterium Marinobacter hydrocarbonoclasticus SP17 degrades a wide range of lipids and hydrocarbons through the formation of oleolytic biofilms with distinct gene expression profiles. FEMS Microbiology Ecology, 90(3), 816-831. doi: 10.1111/1574-6941.12439

Mukai, K., Shimasaki, Y., Qiu, X., Kato-Unoki, Y., Chen, K., Khanam, M. R. M., \& Oshima, Y. (2019). Effects of light and hydrogen peroxide on gene expression of newly identified antioxidant enzymes in the harmful algal bloom species Chattonella marina. European Journal of Phycology, 54(3), 393-403. doi: 10.1080/ 09670262.2019 .1576062

Nagakubo, T., Nomura, N., \& Toyofuku, M. (2020). Cracking open bacterial membrane vesicles. Frontiers in Microbiology, 10(January). doi: 10.3389/ fmicb.2019.03026

Naval, P., \& Chandra, T. S. (2019). Characterization of membrane vesicles secreted by seaweed associated bacterium Alteromonas macleodii KS62. Biochemical and Biophysical Research Communications, 514(2), 422-427. https://doi.org/ https://doi.org/10.1016/j.bbrc.2019.04.148

NCBI. (n.d.). Salinivibrio budaii. Retrieved May 21, 2020, from https://www.ncbi.nlm.nih.gov/Taxonomy/ Browser/wwwtax.cgi? $\operatorname{mode}=\operatorname{lnfo} \& i d=444168 \&|v|=$ $3 \&$ lin $=f \&$ keep $=1$ \& srchmode $=1$ \&unlock

Ohta, Y., Hatada, Y., Miyazaki, M., Nogi, Y., Ito, S., \& Horikoshi, K. (2005). Purification and characterization of a novel $\beta$-Agarase from a Thalassomonas $\mathrm{sp}$. 
Current Microbiology, 50(4), 212-216. doi: 10.1007/ s00284-004-4435-z

Potin, P., Richard, C., Rochas, C., \& Kloareg, B. (1993). Purification and characterization of the $\beta$-agarase from Alteromonas agarlyticus (Cataldi) comb. nov., strain GJ1B. European Journal of Biochemistry, 214(2), 599607. doi: 10.1111/j.1432-1033.1993.tb17959.x

Ramos, K. R. M., Valdehuesa, K. N. G., Nisola, G. M., Lee, W.-K., \& Chung, W.-J. (2018). Identification and characterization of a thermostable endolytic $\beta$ agarase Aga2 from a newly isolated marine agarolytic bacteria Cellulophaga omnivescoria W5C. New Biotechnology, 40, 261-267. doi: 10.1016/ j.nbt.2017.09.006

Rao, T. E., Imchen, M., \& Kumavath, R. (2017). Marine enzymes: production and applications for human health. Advances in food and nutrition research, 80 , 149-163. https://doi.org/10.1016/bs.afnr.2016.11.006

Raveendran, S., Parameswaran, B., Ummalyma, S. B., Abraham, A., Mathew, A. K., Madhavan, A., ... Pandey, A. (2018). Applications of microbial enzymes in food industry. Food Technology and Biotechnology, 56(1), 16-30. doi: 10.17113/ftb.56.01.18.5491

Ruan, Y., Kumar Awasthi, M., Cai, L., Lu, H., Xu, X., \& Li, W. (2020). Simultaneous aerobic denitrification and antibiotics degradation by strain Marinobacter hydrocarbonoclasticus RAD-2. Bioresource Technology, 313, 123609. doi: 10.1016/j.biortech.2020.123609

Schmidt, U., Chmel, H. E. R. M. A. N., \& Cobbs, C. L. A. U. D. E. (1979). Vibrio alginolyticus infections in humans. Journal of clinical microbiology, 10(5), 666.

She, Q., Han, Z., Liang, S., Xu, W., Li, X., Zhao, Y., ... Li, Y. (2019). Impacts of circadian rhythm and melatonin on the specific activities of immune and antioxidant enzymes of the Chinese mitten crab (Eriocheir sinensis). Fish and Shellfish Immunology, 89(March), 345-353. doi: 10.1016/j.fsi.2019.04.011
Smith, R. J., \& Grula, E. A. (1983). Chitinase is an inducible enzyme in Beauveria bassiana. Journal of Invertebrate Pathology, 42(3), 319-326.

Striebich, R. C., Smart, C. E., Gunasekera, T. S., Mueller, S. S., Strobel, E. M., McNichols, B. W., \& Ruiz, O. N. (2014). Characterization of the F-76 diesel and Jet-A aviation fuel hydrocarbon degradation profiles of Pseudomonas aeruginosa and Marinobacter hydrocarbonoclasticus. International Biodeterioration and Biodegradation, 93, 33-43. doi: 10.1016/ j.ibiod.2014.04.024

Su, X., Li, X., Leng, X., Tan, C., Liu, B., Chai, X., \& Guo, T. (2014). The improvement of growth, digestive enzyme activity and disease resistance of white shrimp by the dietary citric acid. Aquaculture International, 22(6), 1823-1835.doi: 10.1007/s10499-014-9785-3

Tanna, B., \& Mishra, A. (2019). Nutraceutical potential of seaweed polysaccharides: Structure, bioactivity, safety, and toxicity. Comprehensive Reviews in Food Science and Food Safety, 18(3), 817-831.

Zhang, W., \& Sun, L. (2007). Cloning, characterization, and molecular application of a $\beta$-Agarase gene from Vibrio sp. strain V134. Applied and Environmental Microbiology, 73(9), 2825 LP - 2831. doi: 10.1128/ AEM.02872-06

Zhu, Y., Gao, H., Li, H., Ni, H., Jiang, Z., Li, L., \& Xiao, A. (2019). Overexpression and characterization of a thermostable $\beta$-agarase producing neoagarotetraose from a marine isolate Microbulbifer sp. AG1. Acta Oceanologica Sinica, 38(2), 96-106. doi: 10.1007/ s13131-019-1349-y

Zhu, Y., Zhao, R., Xiao, A., Li, L., Jiang, Z., Chen, F., \& Ni, $H$. (2016). Characterization of an alkaline $\beta$-agarase from Stenotrophomonas sp. NTa and the enzymatic hydrolysates. International Journal of Biological Macromolecules, 86, 525-534. doi: 10.1016/ j.ijbiomac.2016.01.106 